\title{
Research
}

\section{Social-Ecological Guilds: Putting People into Marine Historical Ecology}

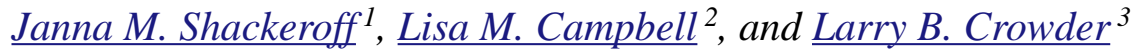

\begin{abstract}
Marine historical ecology provides historic insights into past ocean ecosystems that are crucial to effectively confronting the declining health and resilience in marine ecosystems. A more 'peopled' approach to marine historical ecology is necessary, given the heightened emphasis on human dimensions in marine management. This study examined the historical ecology of Hawaiian coral reef ecosystems through oral histories of diverse ocean experts, representing six traditional, local, and scientific knowledge systems. Based on 61 in-depth interviews with these ocean experts, historical trends, abundance, and distribution over 80 years and a 50-mile region for 271 species emerged. Analyzing trends by ecological guild, e.g., herbivores, proved inappropriate to these data; rather, based on qualitative analyses, five distinct trends encompassing nearly all species emerged in what we term "social-ecological guilds." Ocean expert's observations of change were surprisingly consistent, regardless of their knowledge system, whereas perceptions of change varied widely. The historical picture was far broader and richer when the contributions of six knowledge systems were incorporated, compared to that of any one alone. Social-ecological guilds also matter critically from a management perspective, because understanding how experts from a multiplicity of perspectives observe, interpret, and respond to ecological change can help managers anticipate responses to management activities and perhaps to design better management strategies.
\end{abstract}

Key Words: conservation; coral reefs; local ecological knowledge; marine historical ecology; socialecological systems; traditional ecological knowledge

\section{INTRODUCTION}

Marine historical ecology responds to the rapid global change seen throughout ocean ecosystems (Pauly 1995, Jackson et al. 2001). Historic insights into ocean condition and dynamics, although crucial to effectively confronting the declining health and resilience in marine ecosystems, are often absent (Pandolfi et al. 2003). To assist in setting achievable goals for management and conservation, marine historical ecologists have shown what more pristine oceans produced, and how they operated. Examples include coastal ecosystems (Jackson et al. 2001, Lotze et al. 2006), commercially and historically significant fisheries (Rosenberg et al. 2005), and recreational fisheries (McClenachan 2009). This field has provided insights that "could not have been contemplated based on the limited perspective of recent observations alone" (Jackson et al. 2001: 629).
To date, historical insights into marine ecosystems have been derived primarily from archival and archeological data sets, e.g., logbooks, tax records, restaurant menus, and historic photographs. Marine historical ecology (MHE) recognizes the potential contributions that traditional ecological knowledge (TEK; Berkes et al. 2000), and local ecological knowledge (LEK; Davis and Wagner 2003) can make to describing past systems (Pitcher and Pauly 1998). Though increasing in number, TEK/LEK studies of marine historical ecology are still greatly outnumbered by quantitative approaches, and qualitative and quantitative MHE remain largely separate fields.

Marine historical ecology was founded on an inherently utilitarian principle: to gain insights of past change to provide a more complete historical and ecological basis for marine management and conservation. How well MHE meets such goals, or is integrated into marine management practice, 
remains somewhat in question. We argue this is, in part, because marine management is focused strongly on ecosystem-based approaches and now seeks to include humans in the concept of ecosystems (McLeod and Leslie 2009). MHE stands to benefit from attending to ecosystem-level questions while at the same time better integrating its quantitative approaches with more peopled approaches (Shackeroff et al. 2009), or those more balanced in the treatment of human dimensions along with biophysical dimensions of oceans.

TEK and LEK can provide recent historical insights into marine ecosystems in cases in which there are reports of recent ecological change, or for which contemporary ecological data are limited (Neis et al. 1999, Berkes et al. 2000, Johannes et al. 2000, Maurstad 2000, McGoodwin 2001, Berkes 2004). In such cases, contemporary historical ecologies can be elicited from local people, such as TEK- or fisheries knowledge holders, and in certain cultures with strong oral history traditions, such knowledge can extend to well before the lifetime of currently living knowledge holders. Better integration of TEK/LEK research into MHE will provide the opportunity to get 'beyond the archives' to the people. In doing so, these studies will help to answer concerns expressed by van Sittert (2005), Bolster (2006), and Campbell et al. (2009) about MHE's reliance upon quantitative data, its detachment from historical context, and its characterization of humans as primarily 'the problem' of oceans. However, although TEK/LEK-based historical ecology has addressed single species issues quite well (e.g., Cardinale et al. 2009, Gerhardinger et al. 2009), ecosystem-level historical reconstructions, necessary to remain relevant to marine ecosystembased management $(\mathrm{EBM})$, pose greater challenges and are far fewer in number.

Merging MHE with resilience thinking on socialecological systems (SES) represents one possibility for 'peopling' MHE (Campbell et al. 2009) and for attending to the scale and scope of complex systems. Herein, we put forth a conceptual framework for ecosystem-level MHE derived from multiple knowledge systems. This framework heeds the foundational work achieved by Cinner et al. (2009a, $b$ ), whose work on socioeconomic conditions underlying societal reef use and in linked social resilience and coral reefs, has forged new ground in connecting people to ecosystems. Such research demonstrates empirically how social and ecological change and responses are inextricably linked and experienced across different scales (Berkes and Folke 1998, Berkes et al. 2003, Liu et al. 2007), and provides concrete tools for managing marine ecological function in conjunction with social context, as emphasized by Christie et al. (2003), Campbell (2007), and McLeod and Leslie (2009).

Efforts to incorporate diverse ways of knowing, i.e., Western scientific, traditional, and local, into marine science and management confront questions related to the following issues: (1) attempts to fit qualitative data to quantitative needs (Nader 1996, Agrawal 2002); (2) the legitimacy, validity, and reliability of codifying TEK or LEK into scientific frameworks (Agrawal 1995, Nadasdy 1999); and (3) ethical issues surrounding the 'use' of another's knowledge for purposes they may, or may not, support, such as conservation (Agrawal 2002, Shackeroff and Campbell 2007). Seeking to overcome such issues, Crona (2006) asked fundamental questions about how marine resource use can affect LEK, in terms of the level and content of ecological knowledge about scale and the nature of ecological interactions in the seascape. Research highlighting points of convergence among knowledge systems are few. Much is still to be learned about how to integrate multiple knowledge systems of seascapes, and this paper aims to combine a variety of perspectives toward understanding ecosystem-scale change.

In this paper, we present research conducted with ocean experts on the Kona Coast, Hawai ' $i$ Island to achieve the following: 1) a description of the historical ecology of the Kona Coast from the 1920s to the present. We use interview derived data to elucidate and explore trends in a coral reef ecosystem across a region, namely the abundance and distribution of coral reef guilds; 2) highlighting the importance of engaging a diverse set of ocean experts when collecting historical data, including those holding TEK, LEK and Western scientific knowledge. People observe, and thus talk about, the organisms, processes, and events they value. What ocean experts know about marine ecological change, therefore, differs from person to person. Consulting a diverse group of experts also allows us to expand our attention beyond a few key species and talk about broader trends in the ecosystem. It allows us to see the many facets in people's, and groups of people's, relationships to ecological systems, or what we suggest are connections within the social-ecological system; and 3) an illustration of our efforts to overcome long-standing divides 
between natural and social sciences, between the qualitative and quantitative, and in the context of this research, to integrate various knowledge systems.

We treat knowledge of diverse ocean experts equally, and strive to retain links between data, e.g. numbers of species seen over time, and the social, political, and cultural context in which data are situated. To this end, we refer to marine organisms in the most common terms used by locally-living ocean experts, whether the terms be Hawaiian, English, or scientific names.

\section{SITE DESCRIPTION AND METHODS}

\section{Research site: Kona, Hawai'i}

This research was conducted in the cross-cultural, postcolonial setting of the Kona Coast, Hawai ' $\mathrm{i}$, the leeward, western coastline of Hawai'i Island. Six watershed-reef-pelagic complexes on the coast, between Keahole Point and Kapua, were selected as research sites because they represent the coast's diversity in people, seascape, landscape, and historic context. This research focuses on the historic and ecological change of the region's coral reef ecosystems, where anecdotal reports indicated that reef fish populations had undergone dramatic declines during the 1980s and 1990s, reportedly because of tropical aquarium fish collection. Resource conflicts between competing local resource users ensued, and eventually led to the establishment of a network of marine protected areas that limit aquarium collection and of a community-based management council (Capitini et al. 2004, DAR 2004). Only limited regional, ecosystem-level data existed prior to the late 1990s, when coral reef fisheries studies proliferated to address local concerns and to examine the effects of the management areas (with the exception of Walsh 1984). Given the dearth of historical data and anecdotal reports of change, our research aimed to describe an historical ecology of Kona's coral reefs based on accounts of its 'ocean experts'.

\section{Methods: identifying, interviewing, and analyzing views of ocean experts}

For approximately 24 months over the course of 2003-2007, we identified and engaged ocean experts across the Kona coral reef region, to pursue questions about historic reef fish abundance, levels and causes of decline, and whether and to what extent other aspects of Kona's reef systems have changed in recent history. We define 'ocean experts' as people who hold expert and historic ecological knowledge about Kona's coral reefs and coastal areas.

\section{Identifying ocean experts}

To identify potential ocean experts for participation in this research, we used snowball sampling (Bernard 1988), social network analysis (Hanneman and Riddle 2005), and observations during participant observation research. We conducted more than 200 informal interviews with key informants who were engaged in ocean use and management, and asked them to identify experts whom they believed to be the most knowledgeable about coral reefs on the Kona Coast. These informants identified 204 ocean experts, and we used several criteria to establish our ultimate interview sample. First, we prioritized individuals most frequently recommended (Davis and Wagner 2003). Second, we included ocean experts who represented the geographic range of the coast. Third, we included experts across knowledge systems. Over the course of the research, our original categories of TEK, LEK, and Western scientific knowledge broadened to include six distinct ocean expert knowledge systems: Native Hawaiians, dive shop operators, local fishers, tropical aquarium collectors, scientists, and conservationists. Finally, we sought age and gender diversity among respondents, where appropriate.

\section{Interviewing ocean experts}

We interviewed 41 ocean experts in one-on-one and group interviews, with some people interviewed multiple times, for a total of 61 semistructured interviews (Bernard 1988, Huntington 2000, McGoodwin 2001). Experts described both observations and perceptions of change to Kona's coral reef systems, specifically related to the following concerns: (1) habitat condition, (2) coral reef functional groups, initially assumed to be herbivores, corallivores, piscivores, apex predators, etc., and (3) natural and anthropogenic disturbance and synergies. Observations refer to visible changes, e.g., decline or increase in abundance of a single species, whereas perceptions relate to how experts interpret and explain observed changes. Both observations, in particular what species 
different experts observe, and perceptions may vary, reflecting the ways cultural, social, political, economic, and other factors affect both coastal systems and the human communities connected to them. The depth and scope of ocean expert interviews were determined by the individual's knowledge, and interviews lasted from 1.5 to 6 hours. For all results, pseudonyms are used to protect confidentiality.

\section{Qualitative data analysis}

Data are derived from the several thousand pages of notes transcribed during interviews. Our general approach to analysis was a form of iterative grounded theory (Strauss and Cobin 1994, Baxter and Eyles 1999, Charmaz 2005), where themes that directed coding ultimately emerged from the data themselves. We offer further detail on steps in the analysis as related to this paper's specific interests and findings, where the foci are as follows: 1) observed trends in both abundance and distribution over time and space for groups of species, and 2) perceptions of what caused observed changes.

To elicit trends for groups of species, we first coded observations of increases, decreases, or constancy in abundance and distribution, over space and time, for each individual species mentioned. We derived assessments of change in abundance or distribution from an individual expert's text, e.g., someone who commented on past and current abundance of a particular species, and from multiple experts' texts, e.g., one expert commented on past and another on current abundance (see Table 1a-b). Changes in abundance were both quantitative as well as relative (Table 1c-e). Changes in distribution were defined as a relative shrinking or enlargement of a species' spatial extent over time (Table 1f). We examined trends for all species mentioned, regardless of how many experts mentioned them. Given our methodological rigor in identifying and selecting ocean experts and in interviewing, we treat all data as worthy of inclusion. Additionally, as in Goodwin (1998), an objective of this research was to identify cultural phenomena; in such cases, it was sometimes less important to quantify how many people shared the same observation, and was more important that the observation was made. As a result of this approach, some species are included that do not necessarily meet the conventional scientific definition of coral reef-associated species, such as yellowfin tuna (Thunnus albacores) and 'opelu (mackerel scad, Decapterus macarellus); for some of our respondents, these species are connected to coral reefs.

Once trends for individual species were established, we looked for patterns in abundance and distribution by ecological guild. No trends emerged, an issue we revisit in the Results and Discussion sections. We then looked for patterns shared across species that arose from the data themselves and categorized species accordingly. Finally, we associated these resulting species categories with the types of ocean experts who talked about them. The resulting groups, which we have called "social-ecological guilds" (SE guilds), are described in detail in the Results section. In addition to describing the guilds' trends, we explored possible factors that various experts believe are underlying the changes in Kona's SE guilds. A full presentation and discussion of these results is beyond the scope of this paper, but we offer a brief summary to highlight the importance of the SE guild concept.

The term 'social-ecological guild' was chosen in part to problematize and encourage further discussion surrounding the use of ecological guilds as a functional unit when studying and managing marine social-ecological systems (SES). We recognize that the term guild carries distinct meanings and precedence in different disciplines, such as history and ecology. However, in ecology, which remains the primary discipline underpinning marine management, the concept of ecological guilds, or functional guilds, is considered an extremely important measure of the history and status of an ecosystem (Bellwood et al. 2004), is used as an indicator for ecosystem-based management (Crowder and Norse 2008), and can be found in many of the recent seminal papers of marine conservation and management (e.g., Myers and Worm 2003). However, as we will show, when humans are included in the dynamics of the system, the utility of ecological guilds breaks down. The core principles of marine EBM strongly encourage the study of "ecosystems, including humans" today (McLeod et al. 2005, Crowder and Norse 2008, Levin and Lubchenco 2008). Therefore, given our results, we suggest the importance of a broader discussion surrounding basic design principles and concepts underpinning marine EBM now that the field is opening to human dimensions. As we will show, the functional groups of organisms whose trends influence the SES as a whole are not the same 
Table 1. Qualitative analysis of interview texts. All scientific, common, and Hawaiian names of marine organisms are given in Table 5.

\begin{tabular}{|c|c|c|}
\hline & Data Analysis Issue & Example \\
\hline (a) & $\begin{array}{l}\text { Observations from a single } \\
\text { expert }\end{array}$ & $\begin{array}{l}\text { "Charlie" recalls schools of hundreds of paku'iku'i (Achilles tang) in Kaloko in the } 1960 \text { s, but for } \\
\text { the last decade (1996 to 2006) has counted no more than a dozen at any given time }\end{array}$ \\
\hline (b) & $\begin{array}{l}\text { Observations from multiple } \\
\text { experts }\end{array}$ & $\begin{array}{l}\text { "Elaine" recalls schools of hundreds of paku'iku' } i \text { in Kaloko in } 1960 \text { s, while "Barry" counts no } \\
\text { more than one dozen of the fish in the same area today (2006). }\end{array}$ \\
\hline (c) & Quantitative abundance & $\begin{array}{l}\text { "For decades we would see between } 10 \text { and } 13 \text { lionfish on any given dive in that area. Then, they } \\
\text { all disappeared, and we haven't seen one since." }\end{array}$ \\
\hline (d) & Relative abundance & $\begin{array}{l}\text { "Yellow tang schools were like rivers of yellow, or beds of yellow tulips until the } 1980 \text { s, then } \\
\text { noticeably in decline until the late } 1990 \text { s when you might see two or four fish in any area" }\end{array}$ \\
\hline (e) & $\begin{array}{l}\text { Relative abundance (Indicating } \\
\text { a change catch per unit effort) }\end{array}$ & $\begin{array}{l}\text { We used to go spearfishing and all would choose a fish and only take that one kind of fish. I'd } \\
\text { take manini (convict tang) my friend would take } u h u \text { (parrotfish)... There used to be so many fish, } \\
\text { I would have to push them out of the way to get the one I wanted. After an hour, our lines would } \\
\text { be full. Now a couple of hours, and you get only a couple fish, different kinds. Last week, I got in } \\
\text { the water, and I was excited to see one fish. Just one fish!" }\end{array}$ \\
\hline (f) & Distribution & $\begin{array}{l}\text { Tinker's butterflyfish have been observed historically (1930s) from } 5 \text { to } 180 \text { feet depth. But for } \\
\text { some decades adult Tinker's have not seen shallower than } 100 \text { feet. This is an indication of a } \\
\text { relative decline in distribution over space (shallow depth range) and time (recent decades). }\end{array}$ \\
\hline
\end{tabular}

as the functional groups in the classic sense of ecological guild. Hence, we have coined the term SE guild.

\section{RESULTS}

Oral histories revealed historical trends in the abundance and distribution of 271 marine species, over 80 years and a 50-mile region (Table 2). Initial grouping of species by ecological guild to examine trends proved ineffectual; in some cases trends were hidden, e.g., for butterflyfish (Chaetodontidae), and in others no clear trend emerged, e.g., for apex predators. However, a grounded theory approach enabled us to discern trends that grouped species in a number of ways: historically, socially, culturally, and/or ecologically, and often associated with distinct groups of ocean experts and their associated 'ways of knowing.' We refer to the resulting groups of species as social-ecological guilds, reflecting the fact that these groups of species are linked by much more than biology or ecological function.

Five distinct patterns of changing abundance and distribution emerged and encompassed nearly all species observed by interviewees. SE guilds include the following: (1) traditional species; (2) ornamental organisms; (3) native piscivores; (4) sharks/eels; and (5) invasive piscivores. For the first two guilds, which contained the largest number of species, there were a few noteworthy species that defied the overall trend of the group: honu (Hawaiian green sea turtle, Chelonia mydas) in the traditional group, and butterflyfish and rare species in the ornamentals group.

We summarized guild trends and the exceptions in bubble diagrams (Figs. 1-4, Tables 3). Bubble diagrams are meant to be illustrations of concurrence in expert's observations; these are not meant to be statistically significant representations of oral history data, because it would not be appropriate to conduct statistical analyses on these data. Rather, these are meant to illustrate peoples' words and how many descriptions revealed observed changes that were strikingly similar across groups of species.

In addition to bubble diagrams, we list which group talked about each guild (Table 4) and list a subset of organisms in each SE guild (Table 5). All species' scientific, common, and Hawaiian names are listed (Table 5). When experts observed change for the same species, their observations were surprisingly consistent, regardless of their ocean expert 
Table 2. Summary of interview data and species trends.

\begin{tabular}{ll}
\hline \hline Total species examined & 271 \\
No. species/expert & Range, 13 to 147 \\
No. of experts & 41 \\
No. of interviews & 61 \\
\hline
\end{tabular}

knowledge group (Table 2, Fig. 1). Observations of change over time in most species were triangulated by multiple experts and sometimes across diverse expert groups. Even though there was little disagreement about biophysical trends, experts did not always talk about the same species, even within a single guild (Table 3), and experts' perceptions of what caused such changes were much less consistent.

\section{Traditional species social-ecological guild}

Traditional species are characterized by decreases in abundance and distribution over time, with reductions accelerating from the 1960 s to today. The traditional species guild is shown from the 1920s to 2006, and in detail from 1960 to 2006 (Fig. 1a,b). This guild contains a broad class of organisms from intertidal, coral reef, meso-pelagic and pelagic systems. It also includes a suite of organisms more taxonomically and functionally diverse than in other guilds, i.e., invertebrates, algae, crustaceans, and highly migratory species.

We refer to this guild as traditional because experts commonly refer to these species by their Hawaiian or local names, rather than their English or scientific ones, and many are recognized as significant Native Hawaiian cultural resources in texts of historic fishing and ocean use (e.g., Kahaulelio et al. 2006). In addition, Native Hawaiian ocean experts spent proportionally more time talking about these organisms than any other guild and proportionally more time focusing on this guild than any other expertise group, though most all experts talked about traditional organisms. Although these organisms may be used for subsistence and commercial purposes today, their traditional roles in Native Hawaiian culture are reflected in this label. Ocean experts described change in these species in a variety of ways, and spent varied lengths of time on each. Many conceptualized changes as associated with particular events or use practices: Respondent A: "For my daughter's wedding [30 years ago], we collect 15 gallons of opihi" (Hawaiian limpet, Cellana sandwicensis). [Several women had walked along the shoreline, no more than 2 miles down-coast from their village to collect opihi]; Respondent B: "Now lucky if get one gallon!" (07C.04)

Others related change to specific places: "In the 1970s... in one 15 minute swim across maybe 150 yards, I counted 35-40 pairs of paku'iku' $i$ at the Old Airport, or about 80 fish." [05.05C.06]

Whereas the stories around subsistence species were diverse and far-ranging, two staple foodstuffs and culturally important species for Native Hawaiians that have shown localized depletions, akule (bigeye scad, Selar crumenophthalmus) and 'opelu, exemplified how ocean experts described historic trends in traditional fishes. Many experts observed that the seasonal schools of akule disappeared in the 1990s. This species is locally absent in most but not all of Kona's bays, "Now only place get [akule] is Napo “opo“o [village]" (06B.04). In addition, Hawaiian fishermen expressed surprise about very recent declines in "opelu, a Native Hawaiian staple food fish since ancient times and "number one bait" for fishing (07A.04; 08.31B.06), which has long been considered an inexhaustible resource. At the start of this research project (2004), an elder (kupuna) and renowned fisherman described 'opelu as "an impenetrable resource. We fish 'opelu for thousands of years, and they always come by the 
Fig. 1. Abundance and distribution of traditional species social-ecological guild. The abundance scale on the y-axis of the bubble diagram refers to real numbers, i.e., 1 is an observation of single fishes, 10 is of 10 or 10's of fishes, 100 is of 100 or 100's of fishes, and so on. Relative changes to distribution are represented by different sized bubbles. Thus, a constant size of bubble indicates no evidence of change in distribution (sites inhabited, or range within the habitat) from one year to the next, whereas expanded or contracted bubbles illustrate changes in distribution. This system of representation is used in all subsequent bubble diagrams.

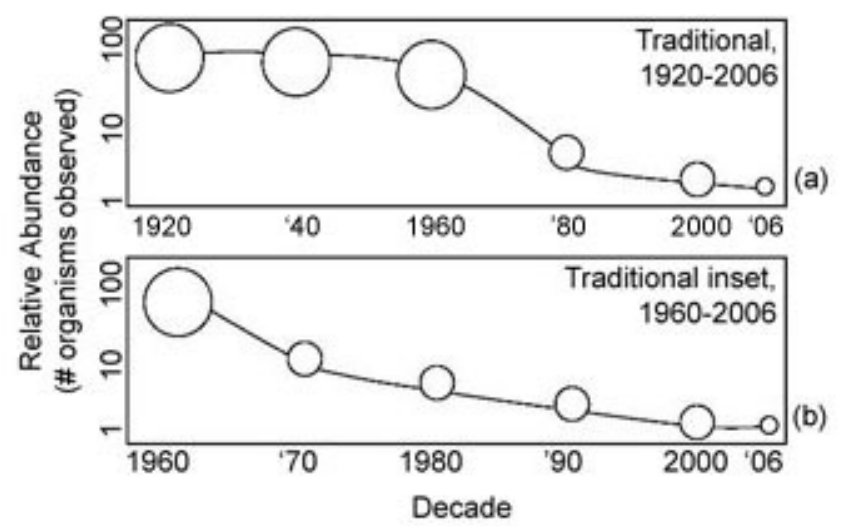

ton. We maybe fish 1-percent, 2-percent 'opelu any year" (07A.04). According to multigenerational fishermen $(08.31 B .06)$, numbers of 'opelu seem to fluctuate on a 7 to 10 year cycle, over which time there may be high and low periods that seem to coincide with good and bad years for mango crops. However, by 2006 'opelu had been "marginal" for several years $(8.31 B .06)$, a less productive fishery than any time in the past six generations of a renowned fishing family. Many of Kona's few remaining, full-time, small-boat fishermen, who target 'opelu and supplement with tuna and diversified methods, were forced to find 'land jobs' because of the unusual and prolonged dearth of this important fish (8.30.06).

Several organisms might fall into either the traditional or ornamental SE guilds based on their use and the ocean experts that most talk about them, but because they follow the trend in traditional fishes and of their value to local people as food, they are classified in the traditional guild. These include some of the most common interview topics: paku 'iku'i (Achilles tang, Acanthurus Achilles), uhu (parrotfish, Scarus spp), and manini (convict tang, Acanthurus triostegus).

\section{The honu exception}

In contrast to the other animals in the traditional guild, and indeed to most other organisms discussed, honu (Hawaiian green turtle) has increased in numbers over the past three decades, following its listing on the Endangered Species Act and subsequent protection efforts. In addition to their increased numbers, ocean experts also discussed honu's changed behavior, observing them to be much less wary around humans than they were in the past. Although all ocean expert groups discussed honu, we included it in this guild because of its traditional importance to Native Hawaiian people.

\section{Ornamental organisms social-ecological guild}

The ornamental organisms SE guild enveloped a wide suite of generally colorful, abundant, or gregarious reef fishes including wrasses (Labridae), angelfish (Pomacanthidae), surgeonfish and tang (Acanthuridae), butterflyfish, gobies (Gobiidae), boxfish (Ostraciidae), as well as invertebrates. Referred to in everyday terms in Kona as 'ornamentals' or 'collected species', they also 
Fig. 2. With consistent distribution, honu (Hawaiian green turtle, Chelonia mydas) have experienced increases in abundance since protections three decades ago. This represents an exception to the subsistence social-ecological guild and ornamental social-ecological guild.

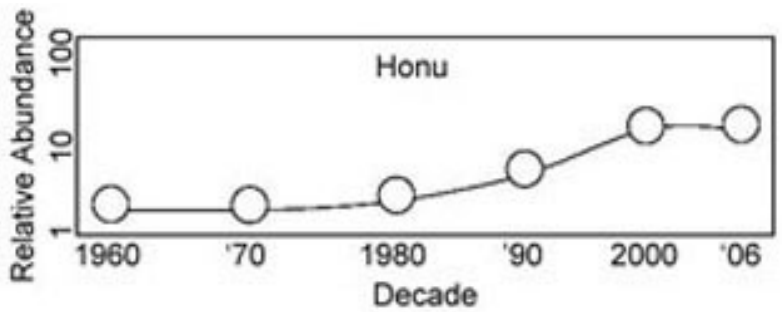

included the cryptic, rare species significant to the dive industry and the tropical aquarium collection trade. Ornamentals were characterized by a reverse J-shaped curve, in which the abundance of adult organisms decreased dramatically and consistently between 1970 and 2000, but experienced a "blip up" (12.04.06) in the past 5 years (Fig. 3a). Ocean experts did not report changes in the guild's spatial distribution over time.

Yellow tang (Zebrasoma flavescens, lau'ipala) exemplified the ornamentals' characteristic reverse J-shaped curve. Prior to the 1960s, yellow tang were so abundant, they constituted a "band of gold around the coastline," visible from airplanes (07.05.06), the shore $(07.3 .04 ; 05.07)$, and through the $1970 \mathrm{~s}$ in the crests of waves (06.14.06). In-water, yellow tang abundance through 1980 looked like "rivers, literally rivers, of yellow tang" in some areas and "large streams" in other areas. Monotypic schools of adults grazed on reefs, and recruitment areas looked like "beds of yellow tulips" (05.22.06). Coincident with observations of decline in a host of other ornamental species, by the mid-1980s divers and Hawaiian experts recall realizing that there appeared to be fewer yellow tang on the reefs. Resource depletions grew more and more apparent to these people, until "on one dive I counted three yellow fish. Not three yellow tang. Three yellow fish, total!" (07.05B.06). Today, however, increases in yellow tang are apparent. In most sites, experts noticed small aggregations of yellow tang again, rather than scattered individuals.

Some fishes in the ornamental guild exhibited distinctly different trends to the reverse J-shaped curve. These special cases, rare species (Fig. 3c) and butterflyfishes (Fig. 3b), experienced either an exaggerated rebound or a muted-to-negligible rebound, respectively, in abundance and distribution since 2000.

\section{The rare species and butterflyfishes exceptions}

By the early 1970s, rare species' populations were so depleted, even absent, on $\mathrm{O}^{\prime}$ ahu's reefs that Waikiki Aquarium employees came to Kona to collect specimens for exhibits:

In 1975-77 when I worked at the Waikiki Aquarium. We came here [to Kona] to collect species that we could no longer find on $O$ ‘ahu. I... remember reticulated butterflyfish [Chaetodon reticulates], C. tinkeri's, Desmo holocanthus the banded angelfish all here. And lionfish [Dendrochirus barberi]! You could see them anytime, anywhere you wanted to here! Oh, I remember longnosed hawks [Oxycirrhites typus] in nice long black bushy coral trees! Not only were these species present, they inhabited shallow areas of the reefs. The sphex [Hawaiian lionfish] and longnosed hawk and Desmo holocanthus and tinkeri were in much shallower areas of the reefs. I mean, today, tinkers can be seen deep, at 300 feet and probably deeper than that; but in those days, we saw them regularly in 70 feet of water instead of having to go to 140 feet or more. And I haven't even seen a lionfish in 7 or 8 years. [4.14.06] 
Fig. 3. Relative abundance and distribution of the Ornamental organisms' social-ecological guild, including the general class (a), and the special cases of butterflyfishes, Chaetodontidae (b) and rare species (c).

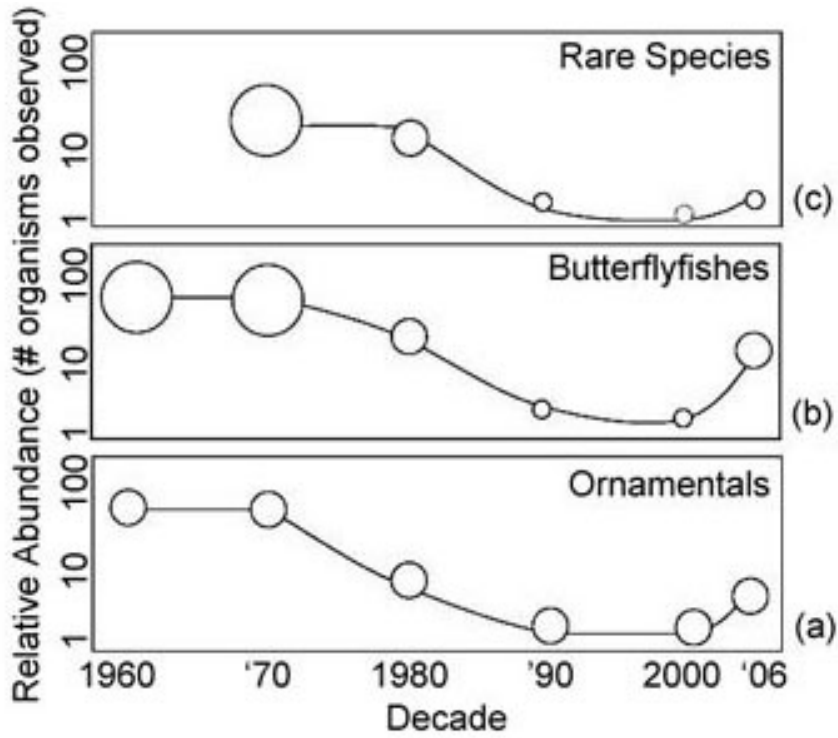

Although the rare species showed muted to negligible rebounds compared to other ornamentals, the butterflyfishes have shown accentuated rebounds. Today, Kona's coral reefs are again populated by "spectacular displays" of butterflyfishes (5.22.06), including some 17 species of the Family Chaetodontidae that were detailed by ocean experts. Teardrop butterflies inhabiting Kealakekua Bay exemplified observations of historic change to the butterflyfish:

In the 1970s on any given day, divers might see 20-30 teardrop butterflyfish on any given dive. About five or six years ago $[1999$ to 2000], I saw one and got excited. Then I thought, 'What's the big deal? I used to see these all the time!' Things have recently gotten better. Generally, that is the case with all the butterflies. So, for example, teardrops [teardrop butterflyfish] had virtually disappeared from so many dive sites, and are finally increasing in Kealakekua Bay. Today [2006], I might see 6 to 8 in any given dive, which I believe means there are a couple of dozen, in total. [07.05A.06]
Ornamental organisms thus showed three distinct reverse J-shaped curves: the muted curve of rare species, the moderate of most ornamentals, and the accentuated rebounds of butterflyfishes.

\section{Native piscivores social-ecological guild}

The native piscivores guild (Fig. 4a, shown with other predator groups) included such culturally important species as ulua (Jack, Carangoides spp. \& Caranx spp.) and kahala (Amberjack, Serioli dumerili). Exhibiting a reverse J-shaped curve pattern slightly distinct from the ornamental guild, the native piscivores appeared to have been in a period of decline in abundance and distribution on coral reefs for several decades, with a rise in the past few years.

On Kona's coral reefs, divers recalled observing these predators associated with schools of akule "so big they look like oil spots. There would be huge ulua and kahala keeping akule herded. They were always there, but you don't see ulua or kahala anymore either. I remember 6-foot barracudas, 5foot uluas." However, "we [divers] never see them 
Fig. 4. Various patterns were seen across predators on the coral reefs. Four social-ecological guilds are represented on this diagram, including: (a) the "Invasives", roi (Peacock grouper, Cephalopholis argus) and ta 'ape (Bluestripe snapper, Lutjanus kasmira), (b) Tiger Sharks (Galeocerdo cuvier), (c) Eels (Anguilliformes)/Reef Sharks (Triaenodon obesus), and (d) Ulua (Jack, Carangoides spp. \& Caranx spp.)/Native Piscivores.

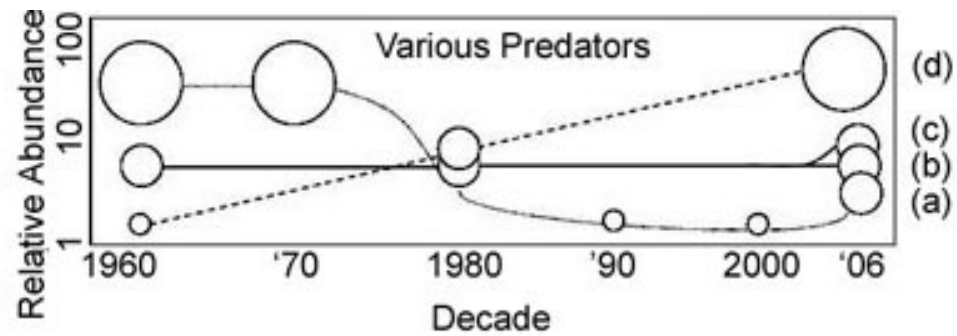

[ulua and kahala] anymore now that the akule are gone" (05.05A.06), an expert reported, making reference to the local loss of most akule $(05.05 \mathrm{~A} .06$, 07.13.06, 07.16.06). In the 1970 s and 1980s, experts reported that ulua, kahala, and amberjacks would rove up and down the coast's reefs, hunting "in packs dominated by adults who are usually accompanied by a few juveniles." Packs of 10 were not unusual, and "one time I counted fifty [ulua]" (05.17.06). In subsequent years, the native piscivore species were seen infrequently compared to the decades prior, until the last one to three years when sightings seemed to have rebounded slightly. Rebounds appeared to be slower than those of ornamental organisms.

\section{Shark/eel social-ecological guild}

Discussions of change in shark (Selachimorpha) populations revealed a single pattern: no detection in change in incidence or habitat use over many decades until a very recent and noticeable increase in tiger sharks (Galeocerdo cuvier) nearshore and proximate to the harbor (Fig. 4b):

There's been a major increase of tiger sharks [Galeocerdo cuvier], especially off of Kaloko in the last year. One of them is around so much, we've been calling it LaVerne. It's a 15-16 footer, and sometimes it'll bask on the surface with the dolphins. It's inside the harbor and out there almost every day. Extremely nonaggressive, but once it came into someone's face. One of our dive instructors saw the shark swimming with a turtle in its mouth. [05.05A.06]

No other sharks mentioned, i.e., white-tipped reef sharks (Triaenodon obesus) and hammerheads (Sphyrnidae), seem to have changed in abundance (Fig. 4c) beyond the typical seasonal aggregations. Nor have abundances of noncollectible eels (Anguilliformes) changed. However, there was a great deal of talk about sharks by ocean experts, and much of it involved ancient cultural significance rather than change in abundance or distribution. Sharks, or manô, featured in legends, were often described as 'aumakua, or protector spirits, ancestral spirits, and are held in deep reverence for various reasons by diverse experts.

\section{Invasive piscivores social-ecological guild}

According to fishermen and divers, roi (Peacock grouper, Cephalopholis argus) and ta'ape (Bluestripe snapper, Lutjanus kasmira) have proliferated both in numbers and extent on the Kona Coast since their introduction (Fig. 4d), particularly the roi since a ciguatera outbreak in North Kona placed restrictions on fishing (06.04). A long-time dive shop operator and one-time commercial aquarium fish collector noted the roi populations' change over time:

The roi, there are so many more now than in the early 1980s. I would get my dive 
Table 3. Summary of expertise group affiliation with social-ecological guilds. All scientific, common, and Hawaiian names of marine organisms are given in Table 5.

\begin{tabular}{ll}
\hline \hline $\begin{array}{l}\text { Social-Ecological } \\
\text { Guilds }\end{array}$ & Expertise groups that discuss each social-ecological guild \\
\hline Subsistence & $\begin{array}{l}\text { Only Native Hawaiian experts provide historic observations from 1920 to 1970, and from 1970 to } \\
\text { 2006 a diverse admixture of experts discussed subsistence organisms. Native Hawaiian people } \\
\text { spend proportionally more time discussing subsistence than any other expertise group, and also } \\
\text { proportionally less time talking about other guilds. }\end{array}$
\end{tabular}

Ornamental (general) Topics of importance to all expertise groups, but feature more prominently in dive shop operators, conservationists, and scientists interviews.

Ornamental (butterflyfish)

Ornamental (rare species)

Native Piscivores

Shark/Eel

Invasive Piscivores
Native Hawaiian experts tend not to focus on butterflyfish at all, while conservationists focus almost exclusively on butterflyfishes. Minor role in interviews of scientists and aquarium collectors.

Topics of importance among dive shop operators, conservationists, aquarium collectors, and scientists interviews, whereas rarely mentioned by Native Hawaiian experts.

Observations principally stem from Native Hawaiian people and dive shop operators, whereas scientists defer to local experts because "sightings of jacks [in scientific data collection processes] are rare" (5.18.06).

Both eels and reef sharks are discussed by dive shop operators and Native Hawaiian people, principally.

All expertise groups talk about invasive piscivores with relatively equal frequency people [passengers on his dive boats] to all crowd around and wait 3 or 4 minutes for a roi to pop his head up. Now, we see 50 to 75 [roi] on a dive. They're not shallower than 30 feet, and I rarely dive deeper than 70 feet anymore with guests, so I can't speak to them being elsewhere. But everywhere I go, the roi populations have really grown. I see all sorts of behaviors today that you wouldn't see before because the roi weren't concentrated enough to do these things. I've seen males standing off, dominant males pushing others around. Periodically, I'll watch a roi eat a longnose butterflyfish, and a couple of times I saw a roi with a juvenile lobster sticking out of its mouth. [05.05C.06]

A diver reported, "huge schools [of ta'ape] at 130 feet, and lots at depths greater than 100 feet in Kailua Bay" (05.05A.06). Another respondent, a successful commercial fisherman who supported a family of eight by spearfishing on the Kona Coast, collected on average over $400 \mathrm{lbs} / \mathrm{day}$ of roi $(07.05$ B.06). This species appeared to be found in shallower waters than ta'ape, which has been seen to blanket waters around 130 feet.

\section{Perceptions of historic change}

Despite surprising consistency in experts' observations of change, their perceptions, i.e., what they believe caused such change, varied far more widely. This was the subject of our work published elsewhere (J. M. Shackeroff, L. M. Campbell, and L. B. Crowder, unpublished manuscript), but a brief discussion is warranted given the importance of this variation for understanding peoples' responses to change and to management interventions designed to address such change. One of the more illustrative examples from this research is related to the decline in ornamental species. All expertise groups agreed on the trend in ornamental species described above, and most acknowledged that tropical aquarium fish collection effected dramatic declines, along with secondary influences by invasive fish predation and 
Table 4. Patterns observed across suites of organisms, or social-ecological guilds. All scientific, common, and Hawaiian names of marine organisms are given in Table 5.

\begin{tabular}{|c|c|c|}
\hline & Social-Ecological Guild & Trend in abundance and distribution \\
\hline \multirow{3}{*}{1.} & Traditional & \\
\hline & Traditional & Decrease in abundance and distribution over time, accelerating in 1960s \\
\hline & \multicolumn{2}{|l|}{ Ornamentals } \\
\hline 2.a & $\begin{array}{l}\text { Ornamental Organisms } \\
\text { (general) }\end{array}$ & $\begin{array}{l}\text { Dramatic, constant decrease in abundance, } 1970 \text { to } 2000 \text {, no narrowing of } \\
\text { distribution. Moderate but constant increase in abundance since } 2000\end{array}$ \\
\hline 2.b & $\begin{array}{l}\text { Ornamental Organisms } \\
\text { (Butterflyfishes) }\end{array}$ & $\begin{array}{l}\text { Dramatic, constant decrease in abundance, } 1970 \text { to } 2000 \text {, stability in distribution. } \\
\text { Signs of dramatic increase in abundance since } 2000\end{array}$ \\
\hline \multirow[t]{2}{*}{ 2.c } & $\begin{array}{l}\text { Ornamental Organisms } \\
\text { (Rare species) }\end{array}$ & $\begin{array}{l}\text { Dramatic decrease in abundance, over days-to-week time periods, localized } \\
\text { disappearances, } 1970 \text { to } 1980 \text { s. Minimal sightings } 1990 \text { s to } 2000 \text {, some signs of } \\
\text { reappearance and/or expanding populations since } 2000\end{array}$ \\
\hline & \multicolumn{2}{|l|}{ Predators } \\
\hline 3. & Native Piscivores & $\begin{array}{l}\text { Dramatic, constant decrease in abundance, } 1970 \text { to } 2000 \text {, narrowing of distribution. } \\
\text { Slight signs of increase in abundance since } 2000\end{array}$ \\
\hline 4. & Sharks/Eels & No consistent change in abundance or distribution across space or time \\
\hline 5. & Invasive Piscivores & Proliferation in space and time \\
\hline
\end{tabular}

other forms of fishing. Most expertise groups considered the dramatic rebounds in ornamentals since 2000 to be a result of the network of marine protected areas (MPAs) put in place to limit aquarium fish collection, along with "the process" of community-based management surrounding these reserves.

Aquarium collectors, however, suggested that natural recruitment cycles complicated this story, in that a natural nadir in recruitment coincided with the most vociferous activism against collection; a recruitment nexus occurred shortly after the MPAs went into effect. Aquarium collectors' perception that collection is not as bad, and MPAs are not as good, as public discourse suggests was supported partly by scientific experts who stated, "Biologically, rebounds [in ornamentals] occurred too early to be attributable to MPAs, but the continued successes are [attributable to MPAs]" (12.4.06). People's perceptions about how and why change occurred, particularly those of ocean experts who play central roles in the marine SES, matter critically to marine management. We explore this issue in depth in the discussion.

With regards to paku'iku'i, the Hawaiian subsistence fish and one of the most collected aquarium species, Native Hawaiian experts explained the fish's nonresponse to management interventions like MPAs as showing "scientists no know what we eat" $(05.31 .06)$. Although several scientists expressed concern about this fish and its importance to Native Hawaiian people by saying: "paku'iku'i are having a tough time of it... not a quick management fix" (12.4.06), most ocean experts generally saw the MPAs as working. That traditional species have not seen increases similar to ornamental organisms, however, has left some Native Hawaiian ocean experts feeling their interests are of little importance to or are being marginalized by science and management. This case illustrated significantly how perceptions surrounding change, in this case change associated with a 
Table 5. Examples of species in social-ecological guilds. Organisms are alphabetized by the name most commonly used (Hawaiian, common, or scientific). If the Hawaiian name was not used, it is not included in this list.

\begin{tabular}{lll}
\hline \hline Hawaiian or Local & Common & Scientific \\
\hline
\end{tabular}

\section{TRADITIONAL ORGANISMS}

$\begin{array}{ll}\text { A`ama } & \text { Rock crab } \\ \text { Ahi } & \text { Yellowfin tuna } \\ \text { Aku } & \text { Bluefin tuna } \\ \text { Akule } & \text { Bigeye scad } \\ \text { Honu } & \text { Hawaiian green sea turtle } \\ \text { Kala } & \text { Bluespine surgeonfish } \\ & \text { Lobster } \\ \text { Maiko } & \text { Bluelined surgeonfish } \\ \text { Manini } & \text { Convict tang (adult) } \\ \text { Ohua } & \text { Convict tang (recruit) } \\ \text { 'Opelu } & \text { Mackerel scad } \\ \text { Opihi } & \text { Limpet } \\ \text { Paku'iku'i } & \text { Achilles tang } \\ \text { Tako } & \text { Octopus } \\ \text { Uhu } & \text { Parrotfish } \\ \text { Umaumalei } & \text { Orangespine unicornfish }\end{array}$

Grapsus tenuicrustatus

Thunnus albacores

Thunnus thynnus

Selar crumenophthalmus

Chelonia mydas

Naso unicornus

Scyllarides squammosus, e.g

Acanthurus nigroris

Acanthurus triostegus

Acanthurus triostegus

Decapterus macerellus

Cellana sandwicensis, e.g.

Acanthurus Achilles

Octopus sp.

Scarus sp.

Naso lituratus

\section{ORNAMENTAL ORGANISMS}

Ornamental organisms (general)

Lau'ipala

Kole

Ornamentals (Rare species)
Bandit angelfish

Chevron tang

Flame angelfish

Yellow tang

Goldring surgeonfish

Orangespot surgeonfish

Pearl wrasse

Ringtail surgeonfish

Psychadellic wrasse

Razor wrasse

Redstripe/Baldwin's pipefish

Yellowtail coris
Desmoholacanthus arcuatus Ctenochaetus Hawaiiensis Centropyge loriculus Zebrasoma flavescens Ctenochaetus strigosus Acanthurus olivaceus Anampses cuvier Acanthurus blochii Anampses chrysocephalus Xyrichtys pavo Dunckerocampus baldwini Coris gaimard
Decoy scorpionfish

Dragon moray eel

Hawaiian lionfish

Leaffish

Potter's Angelfish

Reticulated cowrie

Tiger cowrie

Tinker's butterflyfish
Scorpaenidae sp. Enchelycore pardalis Dendrochirus barberi Taenianotus tricanthus Centropyge potteri Cyparea maculifera Cypraea tigris Chaetodon tinkeri 
Ornamentals (Butterflyfishes)

Bluestripe butterflyfish

Blacklip butterflyfish

Fourspot butterflyfish

Lined butterflyfish

Longnose butterflyfish

Milletseed butterflyfish

Ornate butterflyfish

Oval butterflyfish

Pyramid butterflyfish

Racoon butterfly

Reticulated butterflyfish

Saddleback butterflyfish

Teardrop butterflyfish

Threadfin butterflyfish
Chaetodon fremblii

Chaetodon kleinii

Chaetodon quadrimaculatus

Chaetodon lineolatus

Forcipiger longerostris

Chaetodon militaris

Chaetodon ornatissimus

Chaetodon lunulatus

Hemitaurichthys polylepis

Chaetodon lunula

Chaetodon reticulates

Chaetodon ephippium

Chaetodon unimaculatus

Chaetodon auriga

\section{PREDATORS}

Invasive piscivores

Roi

Ta'ape

Sharks \& eels

Manô

Manô

Puhi

Puhi

Weke

Weke

Native piscivores

Kahala

Moano

Omilu

Ulua
Peacock grouper

Bluestripe snapper
Cephalopholis argus

Lutjanus kasmira
Tiger shark

White tipped reef shark

Yellow margin moray

White mouth moray

Yellowfin goatfish

Yellowstripe goatfish
Galeocerdo cuvier

Triaenodon obesus

Gymnothorax flavimarginatus

Gymnothorax meleagris

Mulloidichthys vanicolensis

Mulloidichthys flavolineatus management intervention, can influence a group of people's perspectives of, and thus the social success of, management overall.

\section{DISCUSSION: HISTORICAL ECOLOGY REVISITED}

This paper presents trends in 271 species grouped into five guilds, over 80 years and a 50-mile region of West Hawai 'i, to describe an historical ecology of an ecosystem. In most cases, coral reef organisms experienced decades of decline followed by some recent recovery. Declines appeared to be on the magnitude of $10 \mathrm{x}-100 \mathrm{x}$, according to experts' observations. These levels of decline were consistent with historical ecology findings reported elsewhere (Jackson et al. 2001, Rosenberg et al. 2005).

Traditional organisms were the notable exceptions on the Kona Coast, where most species have declined, but show no signs of recovery. This was particularly problematic for one expertise group, Native Hawaiian people, especially given the diverse array of organisms constituting this SE guild. Predators evidenced a wide range of trends over time, including three distinct trends among 
apex predators. Ornamental organisms consistently had the clearest recovery as a guild, with the two exceptions being muted response among rare species and an accelerated recovery among butterflyfish.

Qualitative oral history data in this research provided a descriptive and often quantitative account of marine ecological change over time. Across ocean experts, we found widespread agreement in patterns of ecological change, regardless of knowledge system. This lends credibility to the idea that qualitative data derived from a multiplicity of knowledge systems can make substantive contributions to the field of historical ecology, and should help assuage persistent questions relating to the validity and reliability of interview data in MHE, respondent bias due to political or financial motivations, and fallacies of memory, etc. We believe this consistency, combined with the methodological rigor in identifying and selecting experts and in conducting interviews (Baxter and Eyles 1999, Davis and Wagner 2003), made the SE guilds and their associated trends both valid and credible.

With respect to retaining the diversity of expertise in describing ocean change, ocean expert knowledge, including, in this case, six traditional, local, and scientific knowledge types, offer unique insights into past ecosystem dynamics that when combined are more comprehensive than any one perspective can offer. Different people talked about different suites of organisms, sites, and temporal and spatial scales. For instance, scientists deferred to local experts with regards to apex predators because scientific methodologies for coral reef fish surveys tend not to account well for fast-moving, wide-ranging species like ulua. By interviewing diverse ocean experts, these species' dynamics become known. Ocean expertise proved more diverse than expected and suggested by the literature (J. M. Shackeroff, L. M. Campbell, and L. B. Crowder, unpublished manuscript). This diversity is not just important in terms of providing a more comprehensive story, but also for understanding how and why people respond differently to change, and how management interventions marginalize some people and empower others. Marine protected areas, for example, have led to increases in many species, but not those in the traditional SE guild.
Furthermore, in the local context these findings systematically document environmental change previously considered anecdotes and present accounts of change that were not well known in public discourse. A conservationist ocean expert described how a dearth of historical data impinged on local management efforts: "When you don't have the 'before story' [to justify a management strategy], you realize how important it is" (0420B.06). The story of aquarium fish collecting and the decline and recent recovery of ornamental organisms, although lacking much historical data, are well known and are the subjects of a recent $(2000$ to present) proliferation of scientific research (Tissot and Hallacher 2003, Capitini et al. 2004, DAR 2004). In contrast, other stories, like the decline seen across dozens of traditional organisms, have received much less attention historically in management interventions.

We believe there is a strong social-ecological rationale for marine managers to attend to the experiences of all ocean expert groups, such as the Native Hawaiian expertise group with their experience with decline in many traditional organisms. The importance of involving stakeholders integrally in marine management is described by many (Berkes et al. 2003, Pomeroy and Douvere 2008). As illustrated in this study, the richness and breadth of historical insights from a multiplicity of perspectives enables us to see what various groups of people value. Based on our findings and on discussions of expert knowledge elsewhere (Davis and Wagner 2003), we believe that incorporating all ocean experts' knowledge systems in a particular region, at least six in this case, is integral to discovering existing patterns of interaction within the social-ecological system, such as the key peoples and groups, their interests, activities, and effects on oceans, and how they are affected by the oceans, one another, and management activities.

\section{MARRYING KNOWLEDGE SYSTEMS IN MARINE SCIENCE AND MANAGEMENT}

Working with traditional and local peoples is now commonly encouraged and increasingly sought for scientific, resource management, and conservation purposes (Davis and Wagner 2003, Drew and Henne 2006, Kliskey et al. 2009). There has been an active appropriation of TEK, and to a lesser degree LEK and fisher's knowledge, and yet codifying, 
marrying, or joining TEK into Western science is often critiqued politically, philosophically, and ethically (Nadasdy 1999, Agrawal 2002, Brook and McLachlan 2008, Shackeroff and Campbell 2007). Although there is widespread treatment of these issues, rarely have the problems with codification of TEK/LEK been shown empirically. This is one somewhat unintended outcome of this research.

Originally, our study aimed to amass ecological histories across a broad suite of organisms and then present findings in ecological guilds, in terms pertinent to the scientific literature. However, as exemplified by predators and butterflyfish, the ecological framework was not only inappropriate to some data, it also hid historic trends. For predators, categorically assessing historic trends proved less informative than allowing two distinct trends in apex predators to emerge from the data, as well as a third trend in invasive piscivores. For butterflyfish, separating species by ecological function, such as planktivores, corallivores, and herbivores, hid the accelerated reverse J-shaped response these fishes experienced. Considering cross-cultural observations of change from the Western scientific perspective, assigning categories based on ecological function of species, belies the many cultural roles of coral reef species and the many perspectives evident in this research. SE guilds resulted not only from the problems of fitting cross-cultural perspectives into a single, cultural framework, i.e., Western science (Nader 1996), but also arose as a methodological approach to deal with this issue.

Although we do not claim our approach satisfies all of the ethical concerns about appropriating knowledge (Nadasdy 1999, Tuhiwai-Smith 1999, Shackeroff and Campbell 2007), we have tried to provide a more descriptive, peopled approach to historical ecology. To this end, we have let trends emerge from the data and we have represented those trends descriptively. We have preserved the voices of diverse ocean experts by including the way people talk about change, and treated all knowledge from ocean experts as equally valid. In these efforts, undertaken to meet our own commitments to ethical research practice, we believe we have also produced a more comprehensive and clear MHE of the Kona Coast.

We anticipate that some ecologists may argue that trends in social-ecological guilds carry little meaning and that understanding ecological functional guilds remain the way of 'knowing' the state of coral reef ecosystems. What do we gain, for example, by treating butterflyfish as a single guild, rather than as distributed among multiple ecological guilds? We suggest that both science and management gain. First, categorizing strictly by the ecological guild framework proved ineffectual with these data. Instead, letting the data tell the story enabled an explicit, richer story of ecological change with clear trends to emerge. Second, socialecological trends matter critically from a management perspective. Understanding the importance that different people attach to different species and their varied explanations for change can help managers understand various responses to management intervention, and perhaps even to design better interventions. If we examine who talks about what, we can see how the condition of SE guilds might indicate how people experience different aspects of ecological change. For example, although the MPAs are widely lauded by almost all groups as facilitating the protection and recovery of Kona's reefs, they have not led to increases in many of the species valued by Native Hawaiians. This may help explain the gradual withdrawal of Native Hawaiians from the MPA management process and toward other forms of community-based management (J. M. Shackeroff, L. M. Campbell, and L. B. Crowder unpublished manuscript). Herbivores may serve similar ecological functions, but one herbivore cannot always substitute for another in social-ecological systems, in which they may serve entirely different cultural roles or may have very different influences on the social systems surrounding them.

Although local communities are highly complex, they tend to be oversimplified in marine management (St. Martin 2001, Christie et al. 2003, Olson 2005). However, the success or failure of marine management activities is more often than not dependent upon social factors such as conflict resolution, trust, participation, and compliance, rather than biophysical factors (Christie et al. 2003). By eliciting MHE from a multiplicity of perspectives, some of these factors become evident. From the above example, Native Hawaiian ocean experts continue to experience subsistence species declines, whereas dive shop operators, collectors, and conservationists are more positively affected by ornamental improvements. Consistent with evidence of power relationships and environmental change (Bryant 1998, Forsythe 2003), this raises questions about different people's vulnerabilities to 
ecological change and how some people's interests are marginalized by management interventions. SE guilds offer one way for managers to attend to the many perspectives and power relationships in a local setting, as well as to incorporate qualitative data in ecosystem characterization and management.

Resilience science of marine systems, though in its infancy, is greatly needed for managing oceans for resilience (Leslie and Kinzig 2009), in other words, to provide the scientific basis for management to enhance the conservation and sustainable use of those systems and their contribution to human wellbeing (MA 2005). Greater understandings of the key components of and interactions between social and ecological systems are needed, particularly for the multiplicity of perspectives surrounding ecosystems. We suggest that SE guilds provide insights into these interactions as well as the interplay between diversity, redundancy, and disturbance in the social and ecological aspects of Kona's coral reefs. Considering the recent heightened emphasis on including human dimensions in marine ecosystembased management (McLeod and Leslie 2009, Shackeroff et al. 2009) and marine spatial planning (Crowder and Norse 2008, St. Martin and HallArber 2008), SE guilds offer a way to fully develop the rich social landscape surrounding our ocean systems. As we look to manage the resilience of our oceans, these interactions and features will become increasingly critical.

Responses to this article can be read online at: http://www.ecologyandsociety.org/voll6/iss 1/art52/ responses/

\section{Acknowledgments:}

We would like to thank E. W. Glazier, M. K. Orbach, and $C$. Severance for their guidance in this research; P. N. Shackeroff and C. M. Litton for field and research assistance; and Z. Meletis, N. Gray, B. Haalboom, and C. L. Carothers for their input. Support for this research came from the Marine Conservation Biology Institute's Mia Tegner Grant in Historical Ecology, Oak Foundation, Duke Center for Marine Conservation, and Morris K. Udall Foundation Dissertation Fellowship in Environmental Policy and Conflict Resolution.

\section{LITERATURE CITED}

Agrawal, A. 1995. Dismantling the divide between indigenous and scientific knowledge. Development and Change 26:413-439.

Agrawal, A. 2002. Indigenous knowledge and the politics of classification. International Social Science Journal 54:287-297.

Baxter, J., and J. Eyles. 1999. Prescription for research practice? Grounded theory in qualitative evaluation. Area 31:179-181.

Bellwood, D. R., T. P. Hughes, C. Folke, and M. Nystrom. 2004. Confronting the coral reef crisis. Nature 429:827-833.

Berkes, F. 2004. Rethinking approaches to community-based conservation. Conservation Biology 18:621-630.

Berkes, F., J. F. Colding, and C. Folke. 2000. Rediscovery of traditional ecological knowledge as adaptive management. Ecological Applications 10:1251-1262.

Berkes, F., J. F. Colding, and C. Folke, editors. 2003. Navigating nature's dynamics: building resilience for complexity and change. Cambridge University Press, New York, New York, USA.

Berkes, F., and C. Folke, editors. 1998. Linking social and ecological systems: management practices and social mechanisms for building resilience. Cambridge University Press, Cambridge, UK.

Bernard, H. R. 1988. Research methods in cultural anthropology. Sage Publications, Thousand Oaks, California, USA.

Bolster, W. J. 2006. Opportunities in marine environmental history. Environmental History 11:62. [online] URL: http://www.historycooperative. org/journals/eh/11.3/bolster.html.

Brook, R. K., and S. M. McLachlan. 2008. Trends and prospects for local knowledge in ecological and conservation research and monitoring. Biodiversity and Conservation 17:3501-3512.

Bryant, R. L. 1998. Power, knowledge and political ecology in the third world: a review. Progress in Physical Geography 22:79-94. 
Campbell, L. M. 2007. Local conservation practice and global discourse: a political ecology of sea turtle conservation. Annals of the Association of American Geographers 97:331-334.

Campbell, L. M., N. J. Gray, E. H. Hazen, and J. M. Shackeroff. 2009. Beyond baselines: rethinking priorities for ocean conservation. Ecology and Society 14(1): 14. [online] URL: http://www.ecolog yandsociety.org/vol14/iss1/art14/.

Capitini, C. A., B. N. Tissot, M. S. Carroll, W. J. Walsh, and S. Peck. 2004. Competing perspectives in resource protection: the case of marine protected areas in West Hawaii. Society and Natural Resources 17:763-778.

Cardinale, M., M. Linder, V. Bartolino, L. Maiorano, and M. Casini. 2009. Conservation value of historical data: reconstructing stock dynamics of turbot during the last century in the KattegatSkagerrak. Marine Ecological Progress Series 386:197-206.

Charmaz, K. 2005. Grounded theory in the 21st century. Applications for advancing social justice studies. Pages 507-535 in N. K. Denzin and Y. S. Lincoln, editors. The Sage Handbook of Qualitative Research. Sage Publications, Thousand Oaks, California, USA.

Christie, P., B. J. McCay, M. L. Miller, C. Lowe, A. T. White, R. Stoffle, D. L. Fluharty, L. T. McManus, R. Chuenpagdee, C. Pomeroy, D. O. Suman, B. G. Blount, D. Huppert, R. L. Villahermosa Eisma, E. Oracion, K. Lowry, and R. B. Pollnac. 2003. Toward developing a complete understanding: a social science research agenda for marine protected areas. Fisheries 28:22-26.

Cinner, J., M. M. P. B. Fuentes, and H. Randriamahazo. 2009a. Exploring social resilience in Madagascar's marine protected areas. Ecology and Society 14(1): 41. [online] URL: http://www.e cologyandsociety.org/vol14/iss 1/art41/.

Cinner, J., T. McClanahan, T. Daw, N. Graham, J. Maina, S. Wilson, and T. Hughes. 2009b. Linking social and ecological systems to sustain coral reef fisheries. Current Biology 19(3):206-212.

Crona, B. I. 2006. Supporting and enhancing development of heterogeneous ecological knowledge among resource users in a Kenyan seascape. Ecology and Society 11(1): 32. [online] URL: http: //www.ecologyandsociety.org/vol11/iss1/art32/.

Crowder, L., and E. Norse. 2008. Essential ecological insights for marine ecosystem-based management and marine spatial planning. Marine Policy 32:772-778.

Division of Aquatic Resources (DAR), Hawaii Department of Land and Natural Resources. 2004. A report on the findings and recommendations of effectiveness of the West Hawaii Regional Fishery Management Area. Report to the twenty-third legislature regular session of 2005, in response to Hawaii revised statues (188F-5), State of Hawaii, USA.

Davis, A., and J. R. Wagner. 2003. Who knows? On the importance of identifying 'experts' when researching local ecological knowledge. Human Ecology 31:463-489.

Drew, J. A., and A. P. Henne. 2006. Conservation biology and traditional ecological knowledge: integrating academic disciplines for better conservation practice. Ecology and Society 11(2): 34. [online] URL: http://www.ecologyandsociety.org/ vol11/iss2/art34/.

Forsyth, T. 2003. Critical political ecology: the politics of environmental science. Routledge, New York, New York, USA.

Gerhardinger, L. C., M. Hostim-Silva, R. P. Medeiros, J. Matarezi, Á. A. Bertoncini, M. O. Freitas, B. P. Ferreira. 2009. Fishers' resource mapping and goliath grouper Epinephelus itajara (Serranidae) conservation in Brazil. Neotropical Ichthyology 7:93-102.

Goodwin, P. 1998. 'Hired hands' or 'local voice': understandings and experience of local participation in conservation. Transactions of the Institute of British Geographers NS 23:481-499.

Hanneman, R. A., and M. Riddle. 2005. Introduction to social network methods. University of California, Riverside, California, USA.

Huntington, H. P. 2000. Traditional knowledge of the ecology of belugas, in Cook Inlet, Alaska. Marine Fisheries Review 62:134-140. 
Jackson, J. B. C., M. X. Kirby, W. H. Berger, K. A. Bjorndal, L. W. Botsford, B. J. Bourque, R. H. Bradbury, R. Cooke, J. Erlandson, J. A. Estes, T. P. Hughes, S. Kidwell, C. B. Lange, H. S. Lenihan, J. M. Pandolfi, C. H. Peterson, R. S. Steneck, M. J. Tegner, and R. R. Warner. 2001. Historical overfishing and the recent collapse of coastal ecosystems. Science 293:629-638.

Johannes, R. E., M. M. R. Freeman, and R. J. Hamilton. 2000. Ignore fishers' knowledge and miss the boat. Fish and Fisheries 1:257.

Kahaulelio, D., Pukui-Clark, M., translator, P. Nogelmeir, editor. 2006. Ka 'Oihana Lawai'a: Hawaiian fishing traditions. Bishop Museum Press, Honolulu, Hawaii, USA.

Klisky, A., L. Alessa, and B. Barr. 2009. Integrating traditional and local knowledge. In K. McLeod and H. Leslie, editors. Ecosystem-based management for the oceans. Island Press, Washington, D.C., USA.

Leslie, H. M., and A. P. Kinzig. 2009. Resilience science. In K. McLeod and $\mathrm{H}$. Leslie, editors. Ecosystem-based management for the oceans. Island Press, Washington, D.C., USA.

Levin, S. A., and J. Lubchenco. 2008. Resilience, robustness, and marine ecosystem-based management. Bioscience 58(1):27-32.

Liu, J., T. Dietz, S. R. Carpenter, M. Alberti, C. Folke, E. Moran, A. N. Pell, P. Deadman, T. Kratz, J. Lubchenco, E. Ostrom, Z. Ouyang, W. Provencher, C. L. Redman, S. H. Schneider, and W. W. Taylor. 2007. Complexity of coupled human and natural systems. Science 317:1513-1516.

Lotze, H. K., H. S. Lenihan, B. J. Bourque, R. H. Bradbury, R. G. Cooke, M. C. Kay, S. M. Kidwell, M. X. Kirby, C. H. Peterson, and J. B. C. Jackson. 2006. Depletion, degradation, and recovery potential of estuaries and coastal seas. Science 312:1806-1809.

McGoodwin, J. R. 2001. Understanding the cultures of fishing communities: a key to fisheries management and food security. Food and Agriculture Organization, Rome, Italy.
McClenachan, L. 2009. Documenting loss of large trophy fish from the Florida Keys with historical photographs. Conservation Biology 23:636-643.

McLeod, K., and H. Leslie. 2009. Ecosystem-based management for the oceans. Island Press, Washington, D.C., USA.

McLeod, K. L., J. Lubchenco, S. R. Palumbi, and A. A. Rosenberg. 2005. Scientific consensus statement on marine ecosystem-based management. COMPASS Communication Partnership for Science and the Sea.

Maurstad, A. 2000. To fish or not to fish: smallscale fishing and changing regulations of the cod fishery in northern Norway. Human Organization 59:37-47.

Millennium Ecosystem Assessment (MA). 2005. Ecosystems and human well-being: current state and trends. Island Press, Washington, D.C., USA.

Myers, R. A., and B. Worm. 2003. Rapid worldwide depletion of predatory fish communities. Nature 423:280-83.

Nadasdy, P. 1999. The politics of TEK: power and the 'integration' of knowledge. Arctic Anthropology $36: 1-18$.

Nader, L., editor. 1996. Naked science: anthropological inquiry into boundaries, power, and knowledge. Routledge, New York, New York, USA.

Neis, B., D. C. Schneider, L. Felt, R. L. Haedrich, J. Fischer, and J. A. Hutchings. 1999. Fisheries assessment: what can be learned from interviewing resource users? Canadian Journal of Fisheries \& Aquatic Science 56:1949-1963.

Olson, J. 2005. Re-placing the space of community: a story of cultural politics, policies, and fisheries management. Anthropological Quarterly 78:247-268.

Pandolfi, J. M., R. H. Bradbury, E. Sala, T. P. Hughes, K. A. Bjorndal, R. G. Cooke, D. McArdle, L. McClenachan, M. J. H. Newman, G. Paredes, R. R. Warner, and J. B. C. Jackson. 2003. Global trajectories of the long-term decline of coral reef ecosystems. Science 301:955-958. 
Pauly, D. 1995. Anecdotes and the shifting baseline syndrome of fisheries. Trends in Ecology and Evolution 10:430.

Pitcher, T. J., and D. Pauly. 1998. Rebuilding ecosystems, not sustainability, as the proper goal of fishery management. Pages 311-325 in T. Pitcher, D. Pauly, and P. Hart, editors. Reinventing fisheries management. Springer, New York, New York, USA.

Pomeroy, R., and R. Douvere. 2008. The engagement of stakeholders in the marine spatial planning process. Marine Policy 32:816-822.

Rosenberg, A. A., W. J. Bolster, K. E. Alexander, W. B. Leavenworth, A. B. Cooper, and M. G. McKenzie. 2005. The history of ocean resources: modeling cod biomass using historical records. Frontiers in Ecology and Environment 3:84-90.

St. Martin, K. 2001. Making space for community resource management in fisheries. Annals of the Association of American Geographers 91:122-142.

St. Martin, K., and M. Hall-Arber. 2008. The missing layer: geo-technologies, communities, and implications for marine spatial planning. Marine Policy 32:779-786.

Shackeroff, J. M., and L. M. Campbell. 2007. Traditional ecological knowledge in conservation research: Problems and prospects for their constructive engagement. Conservation \& Society 5:343-360.

Shackeroff, J. M., E. H. Hazen, and L. B. Crowder. 2009. Oceans as peopled seascapes. Chapter 3 in K. McLeod and H. Leslie, editors. Ecosystem-based management for the oceans. Island Press, Washington, D.C., USA.

Strauss, A., and J. Cobin. 1994. Grounded theory methodology: an overview. Pages 273-285 in N. K. Denzin and Y. S. Lincoln, editors. Handbook of qualitative research. Sage, London, UK.

Tissot, B. N., and L. E. Hallacher. 2003. Effects of aquarium collectors on coral reef fishes in Kona, Hawaii. Conservation Biology 17:1759-1768.
Tuhiwai-Smith, L. 1999. Decolonizing methodologies: research and indigenous peoples. Zed Books, New York, New York, USA.

van Sittert, L. 2005. The other seven-tenths. Environmental History 10(1):106-109.

Walsh, W. J. III. 1984. Aspects of nocturnal shelter, habitat space, and juvenile recruitment in Hawaiian coral reef fishes. Dissertation, Department of Zoology, University of Hawaii, Hawaii, USA. 